Preliminary communication UDC 111.84(045)

doi: $10.21464 / \mathrm{sp} 32104$

Received: April $5^{\text {th }}, 2017$

\author{
$\underline{\text { Dario Vuger }}$ \\ Ulica ruža 54, HR-10310 Ivanić Grad \\ dvuger@gmail.com
}

\title{
Incubation of Evil: Evil as the Problem of Human Thinking and Praxis
}

\begin{abstract}
This paper discuses phenomena of evil through the works of Hannah Arendt and the crimes of the Nazi regime by identifying in our contemporary world a series of problems with evil which author analyses and defines as a contribution to a future inquiry into the problem of evil as a problem of human praxis. When Arendt writes on evil, she is encountered with a trial to one of the biggest Nazi criminals, Adolph Eichmann in Jerusalem; a trial which substantially influenced the theories of evil to this day. What it brings into the discourse is for the first time fully described evil as a problem of human consciousness, the inner dialogue as a contemplative nature of our being in the world. In the context in which Arendt encounters evil, it is described as banal, as evil that is done by men without any call to consciousness, and also as a deprivation of thought that aims only at mere execution of tasks where evil is global, but the sole act is individual. In other words, it is radical evil that happens with full assimilation of an individual into the system of production, bureaucratization, and industrialization, where mine self (the "I") is subjected to the will of the process that itself remains unknown. In the contemporary situation, on which we will reflect and compare the theories of Arendt and her commentators, evil does not happen as assimilation but rather as a displacement from our everyday life. In that context, evil is incubated in the areas of worldly conflicts, and it witnesses itself through media representations. They create the topographies of evil, and with this creation they deprive us of the duty to think our own actions or to think them inside the framework of evil and good because our everyday life is deprived of the operators with which we could execute such thought process without falling into a discourse of conservative tones of some other form of selective tradition that do not fit the socio-political being of the world we live in, the world of technosphere. Evil has its solid foundations in metaphysics, and it surely governs the discussion of justice (social mystification of good), punishment (justified evil) and others, but that does not mean that evil, begins and ends in its categorical immovability out of the world of movable, the physical world. Evil is a fluctuating point of distress inside the freedom which we produced so we could get rid of it. In the moment in which we deal with our immediate past, it is necessary to "modernize" the thought of evil as a phenomenon that is the inevitable subject of every praxis that hopes to overcome the concrete injustice of our globally and historically taken situation of the spirit.
\end{abstract}

\section{Keywords}

evil, Hannah Arendt, thinking, praxis, incubation, displacement

\section{Introduction}

More than half a century ago - confronted with the aftermath of the second World War - Hannah Arendt reinterpreted the connection between evil and thought. With her original inquiry into the "banality of evil", Arendt marked all the contemporary interpretations of evil, crime and punishment, culminating with the book Eichmann in Jerusalem. The trial of Adolf Eichmann - a high-ranking officer of the Reich responsible for the logistic organization of 
mass deportations of the Jewish into ghettos and concentration camps, and one of the persons held responsible for the genocide known under the name of the Holocaust - was in the centre of numerous philosophical discussions of that time. How could a man, framed by one concrete historical moment, develop an ability for the kind of evil that retarded the Western civilization on such a comprehensive level with consequences that are felt even today? With clarity and a sense of distinction, Arendt - even without the much-needed historical lag - managed to give an essential insight into the philosophical and spiritual nature of evil. On the trail of Arendt's inquiry this paper will expose the context of the Eichmann trial in order for us to be able to take the main thesis of her work as points of dispute, discussion or motivation for further elaborations. This paper will - with this introduction in mind - give an account of evil as a phenomenon as well as the actions and factors it implies, and how can it be banalized, radicalized, latent, or even intelligent, as some commentators speculate.

At the centre of the paper we will highlight the ability and the measure of a human being in disclosing with ones thought. We will pose a question about what is the concrete stake of the "merely not thinking" in the act of understanding one's own evil acts (Arendt 2006:292) while keeping in mind the tradition of ancient Greek philosophy as crucial reference point for Arendt and focus on the matter of inner dialogue of thought, our intellectual surplus that we encounter in the moment when we are left with our own selves - the consciousness. Is the criminal mind capable of reflecting its own undoing? If it is, how does he cope with that reflection while seeing himself in it? To think of evil as one's own is a specific quality of human spirit, as well as it is the ability to disqualify it from our mind, or to say, our ability of self-deception, of that "dark stain on the human race" (Kant 1998:61) that represents our defences against the heavy burden of consciousness that always bares a wish to keep us out of the nexus of our own complex nature. The role of our inner dialogue is composed of calling to responsibility for our acts in the world and as such defines a human being as a person. To give a living being the status of a person means that it can meet the demands that are required with such a status. It is a being of feelings, being that has certain physical characteristics, being that makes things, but first and foremost it is a being that thinks, that has consciousness which carries a crucial role in human behaviour. The ability to think, comprehend, and reflect its thoughts and actions allows a human being to recognize the other as the Other. Giving someone the status of a person is a (bio)political act because only then a human being is invited to communicate with the Other. In that moment it is adopted into an organized society that has its rights as well as its laws, thus it is an act of commitment, and carries with itself the nature of ethical and aesthetic act - one of matter, and of form. If we consider a person that is not capable of reflecting its acts, or a person instrumentalized to the extent where it no longer thinks through his actions, we have to ask about stripping that person of it rights, about its privileged status among the living beings, and about the act of trial as the specific political disposition. That disposition opens the door to two new views that do not have the ability of encompassing the concrete political judgement of one's acts. Living being - in a sense broader than the realm of human persons - can be two things: a "lower" being, a sort of animal, or a "higher" being, transcendental entity, god or Übermensch. On the one hand, lower being are the subjects of biology as well as bioethics - they consider our moral thought on the subject - while on the other hand, the higher be- 
ings are subjects of theology or metaphysics. Thus, the first struggle is about what kind of a trial should a person that does not - historically or ontologically speaking - qualify to be considered a person undergo. It is our political and contemporary liberal philosophy that permits this trivial paradox. The popular social media question outlined it as a conundrum by asking about whether is it okay to "punch a Nazi". Nonetheless, above mentioned mediums of contemplation are not capable of grasping the whole, or event to think politically on their subjects. However, to establish or to broaden the scope of political power and other culturally inherited (human) right to non-persons would pose a new problem because the normalisation of "non-person" entities would generate a new organized community that would again have to - for differentiation purposes - define new non-persons, or to say, entities without a political status (by re-evaluation producing an Übermensch that would then be a simulacrum). Evil nature outside the political essence of the 'evil subject' is taken into consideration by certain cultural and spiritual movements, such as organized religion, that make their own ground for judgement on right and wrong, good and evil, for the sake of internal cohesion of the movement in question. For that reason, we are required to refrain from the thesis about dehumanizing the defendant. In that sense, that which is posed as a problem of thought has its consequences in the practice of an individual, and the society as a whole, that is, has it consequences in the human praxis.

This paper will deduce general remarks on evil as the problem of theory, but also as the problem of praxis. If the posed dichotomy will not provide us with the consequent understanding of an evil act - act that brings pain and obstructs the other human being - as evil in itself, we will be in the need of posing a new thesis, and suggest the new way of thinking about evil. Displaced evil is utilized inside the apparatus that shapes the discourse on evil itself. By using the tools of phenomenological analysis and deconstruction we will offer a set of premises for the consequent "contemporary" understanding of evil, and we will determine in which way our understanding of evil as a theoretical or practical problem aids the debate on injustice, inequality, punishment, and other phenomena connected with some of the significations of evil. Within the discussion we will keep in mind the political consequences of evil acts, but also the politics of evil in the context of ethical dimension.

\section{The problem of evil as a problem of theory}

\subsection{Arendt, Eichmann and conscience}

Adolf Eichmann was abducted in 1962 in Argentina by Mossad, and was brought to trial in Jerusalem for the crimes from the time of the Second World War. Putting the virtual spectacle aside, the role of the trial was to finally resolve the harsh past of the Jewish people, and return verdict on the Nazi crimes. The trial went smoothly, accompanied by numerous press materials, at some point going as far as providing live feed. Hundreds of journalists were reporting in full detail the spectacle of confessed sufferings staged to amplify the horror of the man standing in front of the people he tried to eradicate. However, theoretical consequences of this trial, consequences for our contemporary understanding of the problem of evil, are of the utmost importance. This paper does not rely on the contemporary commentators of Eichmann before Wichmann, Eichmann trial or Eichmann after Eichmann, it concentrates on the original contribution to the above mentioned phenomenon that 
would consequently come close to a form of Eichmann behind Eichmann. We should still keep in mind three essential moments of this introduction as three points that we are now opening a dialogue with: 1) the virtualisation of the trial that acts as a precedent insofar as it posed a cathartic gesture of the trial as an event that is synonymous with the judgement and punishment; 2) spectacle of the trial in the sense of "a social relationship between individuals, mediated by images (...) that is a view of the world that objectified itself" (Debord 1999:36) role of the trial in the closure of historic moment, a situation of closing the story where the same story was unleashed into the unstable media exposition.

The Eichmann trial showed us how the law (or the will of the law) cannot be rhetorically played over, even though the trial showed its utmost weakness exactly in that point. It was predestined for a structural distress with the testimony of the accused as being an innocent bystander. That gave way to a thought that this is actually more or less an innocent man tangled in the web of criminal organization of totalitarian regime of power. Structural weakness in this phenomenon was increased with the mediatisation of the trial, and more or less known outcome of the case in question that was certainly interesting, essential, and frightening, but defined and resolved by its context. From the intellectual aspect, the trial represents a phenomenon that executed the initial exposition of extensive theory on evil which is, with the constant reference to Nazi crime, in development ever since. Evil reveals the paradox at its foundation; that it is not possible to subject it to theorization. Rather, it is the intrinsic signifier of a failed institution. To thematise evil as something more than an ontological segment of the opposition of good-evil means to set it within the world as a justification for, in some cases perhaps inconceivable, consequences of an action. "And so it can be said that 'we', people, are sooner the results of our coincidences than out intentions" (Svendsen 2006:185), or rather, as Odo Marquard claims, it is the matter of the style of "life that maintains equilibrium through the ability to compensate for evil with beliefs" (Marquard 1989:42). Evil as a problem banal or radical, as being affected by the appearance of the automatized bureaucratization of mechanisms of repression, execution and destruction, couldn't have been properly subsumed in Jerusalem because this type of mass evil can't be properly subsumed politically or juridically (Arendt 2006:292). In that sense, evil should be observed peripherally, as relocated, and it should be placed into the more complex compound of meaning composed of today's political, or rather biopolitical, relationships.

As opposed to deeper psychological and psychoanalytic attempts to clarify the massive abyss boulders that we feel while thinking about Eichmann and Nazi crimes on the level of our own comprehension of the phenomenon, cultural theory and history can serve as fertile ground for contemplation, although it could represent yet another blow struck to ethics and the philosophy of moral sentiments in its consequence. Moreover, with the paradigm of modern aesthetics and with Hegel's historical progression (Hegel 2001) at mind, in which every form of expression isn't possible in every historical era, can we understand the creation of un-thought, the change of conscience into empty conscience? Is it possible that the work of the cruellest transgression over humanity was banalized to such an extent that in a time reckless behaviour, which today is considered immoral, was truly trivial, mechanized, and devoid of ethical questions, or rather that morals, at best, represented a contingent point of activity in the execution of the task assigned to those people? That 
wouldn't imply that those people were devoid of virtue and feeling, that in their insignificance they became radical to the point at which they were reduced to conductive material for the Führer's will. It would mean that they were devoid of any ideology and indoctrination and that their "regularity" reacted to the external as it would to a job, a work habit of simple collection, registration and dissemination - a routine. What if indoctrination avoided the officials of the Reich, and acted only externally, affecting the initial system of the legitimization of power - the elections at which Hitler was elected? It set the path of progressive normalization which, in the given historical moment, managed to successfully bypass the 'path of ideology' in order for the Nazi program to find itself at the very core of a new way of life. There is nothing religious or heroic in them, there is no instinct of honour, lust or hate. Officials of high bureaucratic institutions of the Reich are but small segments of a machine, a comprehensive system in which they appear as a subject-less point of the point at which crime transforms into act. That is why Eichmann, the official, "only" did his job, but that is also why he was a criminal, although neither of the two ascertainment's is directly defendable through what was then thought to be the conduction of justice. Every trial against an individual's Nazi behaviour is a trial against Nazi crime in general, and, as a result, the verdict has to be general, and verging on abstract. It is also a call for opinion on the cruel nature of our everyday life, and the banality which shouldn't be merely accepted, but recognized through one's own thought process. To conclude, ideology and indoctrination assumed an aesthetic form - it formed a specific sensory regime - which preceded political legitimacy and propaganda that historically determined things. Aesthetics as a meta-political framework in the creation of society acts substantially unhistorically (Badiou, Ranciere).

It is in this sense that a series of adapted or endorsed dispositions on the valorisation of reality based on the identification of the referent appear. Quite often, evil is identified as an enemy force, and the humane (as opposed to the dehumanized) is understood as moral. Human beings act morally, and evil is (one of) the political orientations. Is it not that such positions accentuate the dehumanized state of critics? Svendsen's review of Hannah Arendt's attitude (Svendsen, 2006:149) on Eichmann's understanding of personal responsibility and the evil nature of his actions appropriately brings doubt into whether Eichmann was truly aware of all the evils and injustices that he brought upon Jews but has, in giving his moral subject in to the heteronomy of will, decided to part with this responsibility. The aforementioned has consequences in what Hans Jonas will thematize in his Principle of Responsibility (Jonas 1990:20 and further), consequently also Hösle in The Philosophy of the Ecological Crisis (Hösle 1996:73). They claim that one of the possible solutions to the incredible ease of the elimination of another life is in the widened state of our consciousness of happening. The culprit in the era of long-distance wars no longer has an immediate encounter with his victim and no longer feels the consequences of his actions directly - if at all. The state of responsibility has been disqualified by the mediatisation and technicisation of war. Evil no longer happens in the place of performance and in this medial contingency, it is incubated in order to be actualized without any mediation of thought. Devoid of any emotional or moral framework, the criminal actions and the criminals of Reich, and of any totalitarian order in general, especially of those that are initially realized by general public consensus, hold within them elements of incubation, preparation and finally exposition. 


\subsection{Evil and Modernity}

"Camps aren't designed only to exterminate and degrade human beings, but also to serve as an experiment of the elimination of spontaneity as a virtue of human behaviour in general and the transformation of human nature into the commonplace, into something even different from the animal; because for Pavlov's dogs we know - it was trained to eat when the bell rings, not when it's hungry - it was a perverted animal."

(Arendt 1951:438)

For Hanna Arendt, the idea of the dehumanization of human nature was crystallized, especially in those that conduct violence. What is left is to direct her analysis with a valid interpretation of the state of general awareness (of the West especially) about the evil that it is doing to the mind and the body of its own being today. The identification of the "perverted" state of humanity can also be linked with the appearance of the technosphere, the pervading paradigm of reaction-counter reaction that includes the elimination of spontaneity from human everyday life, and to which we are all bound to. It is primarily realised by a demand for the subtle realization of the human as an acceptable machine with no substantial human character. Such character in general appears to be redundant. Truly, the type of knowledge required for the realization of such an act must be first and foremost (in the need of realization) identified with one's own goal and subjectivity must be eliminated as an act in order for the bureaucratic state and its apparatus to be transformed into an activity. In doing so, it passivizes the individuals that are meant to be subordinated, so that we could later determine the position of the fascist ideology as a static placement with a fixed identity (Birmingham 2003:88). To understand our distinctive interpretation of the term technosphere I quote Croatian philosopher Žarko Paić, who defined it as "the self-organization of life in the state of an artificial mind" (Paić 2015:5).

In Hannah Arendt's consideration of evil, just like in papers on this topic written after her studies, a living political problem appears per se. It is an assumed part of a public debate, it is subjected to artistic contemplation, or rather it is also an object of aesthetics. Evil begins to actively live in culture, i.e. it appears as its object. In certain cases, it also becomes the aesthetic object of desire, even if it's about an evil like hibrisu or nemezisu, doom or antagonism, or about what we see in Warhol's graphics, or on the war photographs anonymously hung at gallery sales and museums (Vitaljić 2013:177), a place of desire for the scene behind in which "the humiliated conception of beauty is hidden" (Sontag 2005:60). In cultural production, therefore, the concept of evil, as well as the concept of ugliness appear, paradoxically, as good in the sense of commoditised goods. The argument of evil which exists as a latent area around a world crucified (stretched) between bureaucracy, consumption and diffusion (Sućeska 2008) is unsustainable because of its very existence, and it is available and represented as the part of political and cultural discourse. Evil must be exposed, or rather it has to be looked for, which means that it has structurally become the dominant network of relations in the world. Therefore, it is localised, organised and institutionalized into the apparatus of the dominant political power. To this it was led to by the transformation of political regimes of our most recent history. The political system itself isn't evil (democracy) and its segments conceptually do not deal with evil (neoliberal capitalism). Rather, evil is incubated in the balance between action and 
reaction in the total political topography of freedom, humanization, and the enlightenment of the people as well as the industrial production of the social domains. Nations that avoided democracy, or rather, nations that avoided the West are, with the "help" of former colonist powers, turned into incubators of evil, of its idea and power, in order for the categorical system that operates the deliberation of evil to properly coordinate it, in so doing allowing the control of influence of the discourse of evil flow into the public sphere. The culture of the topographic relocation is a way for cultural programming to separate the phenomenon from its ethical, aesthetic and other dimensionality. In the same way we contemplate the depictions of evil, separated from our everyday life, as a scene of a phenomenon that doesn't affect the immediate categories by which we understand connotations and consequences of our own immediate actions.

That is why it is especially important to highlight the violent whimsies of our cultural life, its shifts and transformations that have consequences that affect political culture, ways of understanding and life concepts. Culture is active but, for its stability, it must feign a benevolent passive stance on which tradition is based and from which laws and norms can later sprout. We are no stranger to both-sided games of politics and culture either, and that's because tradition can most certainly be understood as an ideology. Moreover, the establishment of tradition is preceded by the culture and ideological aspirations of the people that do the establishing. Tradition is the selective picking of the past as the establishment of a modern value, led by the concrete idea of cultural development (Williams 2006:42). Thus, although we mark the tradition as ideological, its firm base gives foundation for the creation of history, as well as the overturn of communication within the culture one lives in. In order to commoditise evil, we must relocate it from the horizon of our everyday life; it must be geographically distant as well as shown by the media as distant. Only then can it maintain its traditional frame of relations of shock, derealization, etc.

\subsubsection{The Abolition of Theodicy and the Creation of the Technosphere}

The conduction of the politics of cleansing the world in order to establish it as total firstly required a system, a nexus of bureaucracy; the preoccupation with the archive as a meta-system that ensures the transparency of the structure of responsibility. It ensured the existence of the counter product: the lack of responsibility. The appeal to conscience, which demands human's otherness, is opposed to by the reference to the structure culminating in the highest role model which is no longer comparable to our conscience - God - but rather to our world - a dictator (cf. Birmingham 2003:85, 86; Löwith 1949). The horizon of our conscience is located in the real, the modern, and no longer extends into the transcendence. With the disqualification of our conscience as the theology of progress appears a sharp diagnosis, set up by Hösle during his Moscow classes:

"Today, we can do things with consequence which we can only predict with the greatest of effort. (...) Should these consequences finally reach the conscious mind, inborn moral instincts (conscience) are no longer enough to prevent man's actions, which will have repercussions over a long distance (...) about whose negative valuation there is arguably a consensus. (...) Our technology today has far-reaching consequences - and the people that serve it have not yet learned to spread traditional love toward their neighbours to the love for the distant." (Hösle 1996:73-74) 
Therefore, radical evil is understood as an evil set within a system; a system which, as naturalized system, became the substantial horizon of our world in which a metaphysical about its foundation plants itself. The kind of people required for this type of evil, the radicalized remains of human beings that Arendt also describes, are people that live in the technosphere (Paić 2013:92, $485)$. It is a place in time that replaces its production capacities with industrial consumption, and turns its created scenery into the new nature. The time of birth of this world is the history of the World Wars; the transformation of political regimes through the radicalization of all existing ideas (especially reevaluation), dictatorships, the transformation of people in such a way that we could place them within the ideal of community which rests on exclusivity, hierarchy, imposed singularity, and one-dimensionality.

Radical evil, posited through Kant's (Kant 1998:56) and Arendt's work, was critically examined by Alain Badiou, who emphasised an important semantic paradox that has consequences in practice. Radical evil, as the type of evil that reached its pinnacle in Nazi crimes (Badiou 2001:61) is the type which is immeasurable but, in its critical realization, it is true evil which must always be measured (Badiou 2001:63). Indeed, measuring it again and again presents evaluation as the constant questioning and disqualification of evil today as opposed to the magnitude of the past. In that sense we can once more refer to the technosphere as a political program of the modern transformation of country and economy. The technosphere no longer differentiates human beings from machines. This greatly changes relationships between people, and the understanding of the sovereignty of people. Moreover, law is displaced by the new logic characterized by the politics of evaluation, preparation, and execution of an operation according to the statistics and the logic of an extraordinary situation, by which politics actually becomes logistical occurrence overloaded with the system (Paić 2013:92).

\subsection{Excursus: Mortality as evil}

Throughout history, on the trail of platonic dualism of the soul and the body, countless philosophers have viewed corporeality as a "negative" side effect of imperfect beings. For example, Plotinus asserts that "to materialize in such a way and to weaken is the decline of the soul because the entirety of its powers to not reach actuality" (Plotin 1984:81). In accordance with that, mortality, as a feature of the material body, is tied with evil because it appears as an exemption of the being (Gerson 2006:102, 108) which is in the disfavour of our perishing bodies.

Today, within the sphere in which technology becomes the second human nature, it is required to once more ask the question about what is the status of death and corporeality in society and whether medicine has crossed from its humanistic role into an apparatus of biometric and biotechnological governing structure of the world. Cultural differentiation of understanding mortality and vitality is a complex temporary socio-economic and political problem of a deeply contextualized set of civilization and cultural values. Advancement of science and technology, faith in progress or fear over regression control the view on death. History can as well be viewed through this "cultural key", i.e. the development of awareness about death as the separation from life, or as awareness of life as the entangled sum of qualitative markers such as health and longevity. Disposition towards life is greatly defined in accordance with the development of science, first and foremost of medicine. With the progress of medicine, disease is eliminated from the immediate everyday life; it be- 
comes exotic and foreign. Since the premedicinal mystic diseases (the inner evil), first they were exteriorised, and then entirely removed from the human experience. Sickness represents a distancing from the standard for which medicine (and related human health sciences such as nutritionism) advocates, so it should be fought against. The goal isn't to prolong life, but to maintain it, and death, which was once thought of as evil, is no longer an object of fear, but at the same time the process of coming to it is receipted as natural evil whereas medicine is good, and death is a "wicked" necessity. Equally so, disease and death are becoming exotic, something that doesn't happen to us, but rather to "others". Through the secularization and technicization, man's space of transcendence is closing, and his mortality is becoming the final limit of his life and hope. The place that philosophical-religious culture had in repelling the thought about the end was replaced by the progressive nature of the culture of techno-science and capital maintained by the human desire to prolong life. The terror of the technology of the world brings with it the potential to unmask the evil human nature as a birth of human's second nature in a battle for survival within a self-created world. In that sense, evil is a necessary (by-)product of our freedom, and it doesn't point to a thought-problem, but rather it points towards action (Amherdt 2010:488). Evil that points us towards ourselves creates assumptions for its observation in the current historical moment. Here, it isn't at the end (death) or at the beginning (birth), but is understood within the context of the process of life.

\section{The displacement of evil and its incubation}

Displacement is that which, in essence, determines the topography of evil in today's world-historical situation in which evil is measured, calculated, politicized, and one-sidedly represented as existing in the current focus of world conflicts. In the West, conflict is not permitted. Would-be protests, raids, and other expressions of civil disobedience have been successfully assimilated into a system which is organized in a way that it tolerates deregulation on the level of subversion. In accordance with that, no instance of this process can be called evil because the procedurality of human freedom in the West can't contain evil as its own instance, but rather as individualism; as a call for the deprivation of liability. Displaced evil is unseen, it doesn't fall under the apparatus of latency, but of incubation. Physical life is exempt of evil because it is located in the mediasphere, a place of floating information and codes, i.e. a program that structurally creates a highly organised network of components that reserve evil for a series of exotic topographies in which our incubations of evil and violence is located also; it is a network of everything that we thought we could abolish with new political, economic, and socio-cultural paradigms that operate our everyday lives. We talk of power relations within our Western world because we have, or so we think, rid ourselves of force - the crude duct of political will. Still, it hasn't vanished, rather, it's been displaced into the field of incubation, into places marked by conflict, and the games of force, rather than power plays, ever since the end of the Second World War, and peaked during the collapse of the USSR. Therefore, speaking of evil in the context of personal modernity, incubation itself appears as a practical problem. The impossibility of our speculative dismissal of what is evil results in a policy oriented towards the establishment of the topography of evil which represents an attempt at eliminating evil as a problem within the real sphere of the West. The evil of individuals within the West is no longer evil as such because it doesn't operate though its maximal instances. It is interpreted as a 
deviation from the norm, or rather the violation of the law, which again isn't evil in itself because the law isn't a prophet of good, but of the structure of the functioning of the society.

Incubation is therefore a phenomenon which appears as a result of the cleaning of public space from the signifier of evil who, referring to the discourse on evil and its lower instances (injustice, inequality et cetera), acts through the displacement of the higher discourse into places which are to be considered (by politically-economic or culturally-ideological will) evil. Evil is incubated in the way that it can, in its displaced position, grow, implode, and appear in the West as a form of reaction of good to evil, and the unfit, in order for the kind of evil represented by the media to be directed towards a nation, an individual, a civilization or a race as a generalized ideological good. It is a precondition of our understanding of terrorism and all the contemporary phenomenon related to evil.

Every incubation is a political act but, considering the historical, or rather, temporal disposition within the context in which it operates, incubation appears as (1) aesthetic-semantic, (2) performative-medial, and (3) philosophical-metaphysical. Moreover, although it is possible to offer a series of divisions considering the quantitative involvement of actors within an evil happening, we have to sate ourselves with this as the foundation for future rebuttals or debates which will offer stricter and purposeful conclusions in which the idea of incubation presented here will appear as a modest foreword or the object of criticism and debate. Incubation can be a bio-political act just as it can represent the totality of relations within a certain society or community. Incubation can also be viewed, of course, as a cybernetic paradigm if we consider its development in modern French philosophy, primarily in the work of Gilles Deleuze, and of his spiritual predecessor Gilbert Simondon, most notably through the concepts of meta-stability, individuation, and techno-genesis. Evil can appear in the field of immanence, and one should deal with it through the understanding of its technical, intelligent nature (Baudrillard).

An act in which the feeling of time is transposed to the realization of political will, as was the case with the legitimization of Nazism shortly before the coming to power in Germany, is a type of incubation in which terms that will later be important markers for the evil that is yet to come are absorbed and politicized through public discourse. It happens primarily with the integration of the word "Jew" within the complex of public debate and political configuration (Badiou 2001:65) as a signifier of the German, and of its interior territory of cohesion of power, with which there comes the exposition of the political life of evil before it itself became a matter of political discussion. It is a way for the normalization of a system in which ideological regimes are subsumed into the regime of sensitivity (mentioned in the introductory segment), into aesthetic disposition. The other type of incubation, therefore, has a temporalhistoric status because evil happens simultaneously with incubation in which signifier and signified are topographically parted.

The mediatisation of war is the first act of the eccentric positioning of evil in what we can call evil topographies, areas of constant focus of conflict which often coincide with material sources of power of a certain segment which participates in the very positioning (for instance, wars for oil). Other than evil being represented as a battle for resources, it represents the very conflict as an existential aspiration and necessity. Evil serves inasmuch as an instrument of legitimization of political goals, as much as it serves as the neutralization of the area of everyday life, especially in the West. Evil is part of the execu- 
tion of a certain goal, an evil as an event is transmitted or experienced as an explosion, while in the first aforementioned model it can considered to be an implosion.

The philosophical incubation of evil is happening through the theoretical valorisation of evil, primarily as a part of the historical process wherein the final support in the real placement and understanding of evil from reality is collapsing. Hegel's philosophical program, as well as other relevant writings from the period of German idealism, has indicated the location of conflicts. Peril and war were important components of the progression of history. The theoretical valorisation of evil is important because it offers assumptions for the practical understanding of evil. In that sense, evil can be valorised qualitatively, quantitatively, and theologically. In the history of philosophy, and especially in the philosophy of history, apologies of evil are often found, for instance in Hegel's work, but also in the philosophy of politics and social philosophy evil appears as a way of understanding human nature, or more precisely as primal (biological) human remains. Taken together, the components of the incubation form the explosive composition of totalitarian regimes, and lead to general insecurity in the capturing of evil in its substantiality as a practical act.

Incubation signifies within itself a certain inability of the human subject to suppress evil, and, more importantly, evokes his will as an ability to manifest it, just as the consequences which come from it. The process of incubation as a localisation and a carrier of evil isn't a process driven by good intentions, or intentions of controlling evil, but rather the directed cultivation of evil. Moreover, like many theoretical dispositions, the incubation of evil seems like an intuitively justified thesis in a historical sense. Instead of understanding history as a resolution of class antagonism, the process of incubation as the localisation and bearer of evil isn't a process driven by good intentions. As a progression or circular movement, it can be understood as history intertwined with micro moments of cultivating the contingency of evil. As long as evil operates only as an ontological term, it is impossible to avoid the mystification of evil within human everyday life, a regression into a state in which evil is spiritual strikes deep. Evil has deep roots in metaphysics and is subject to discussion of its righteousness (societal mystification of good) or in punishment (justified evil), but that doesn't mean that evil starts and finishes in a categorical immobility outside the movable world. Evil is to be thought of as a fluctuating point of distress within freedom. Alongside all the evil which is part of our historical awareness, it cannot be "in any way quietly (in a Hegelian way) classified among the passing necessities of the Historical process" (Badiou 2001:64). The role of historical thought is that, in finding the important things firstly in ourselves, a possibility is created for asking the question that has to be determined by terms that are offered to us as a conceptual turning point of our understanding of our own moment.

The task to present the problem of evil as speculative reveals to us its practical nature. Evil as series of the symptoms of "sick" modernity is, naturally, a direction to action, and in that view we are offered with certain answers that must be valorised and from them create an instruction as a counterweight for the self-sustaining systems of incubated unrest. Political action, the remembrance of victims, religious arguments and arguments of wisdom (Amherdt 2010:495) are, of course, types of answers that demand elaboration within the understanding of evil as being incubated and displaced because they are also part of the "life" of evil. In order to reveal the "path" of evil, it is important to 
understand the way in which the world functions within interdependent areas instead of viewing the moral valorisation of the side-effects of this process. Therefore, incubation signifies a process in which evil as a thought and as a practical potentiality appears in a controlled state like a practical manifestation, and as a commoditised state as a thought, aesthetic project or an ethical problem. The status of incubation, the placement of concepts into our everyday life is, in essence, a constant anticipation of the finalization of a process that happens with an explosion, implosion, a philosophical exposition or an artistic disposition.

\section{Conclusion: The burden of conscience}

Dehumanization of both perpetrators and victims is a shift in moral horizons directly related to the would-be impossibility of thought. As many commentators show (Svendsen, Arendt, Levi, etc.), Eichmann and other high officials of the Reich had moral considerations - although suppressed by duty and law - but not towards the dehumanization of a heap of prisoners. Of course, if we're talking about dehumanization as the establishment of completely specific and exclusive sensory field - the regime of the receptivity of the human - we interfere in an important problem of aesthetic moulding. Their possibility to tune out thoughts of the monstrousness of their own actions is the result of a prefabricated status of their world which is identified with their work and task. The short-sightedness of these tasks in Eichman's case is yet another circumstance according to which his choice "not to think" is not a choice for himself but out of necessity, because of the nature of his work, an expected disinterest for the product of his work just as would occur with a bureaucrat or a factory worker. That is why the most difficult task appears to be: to prove to the guilty his guilt in the exact sense by which he is charged of being guilty (Svendsen 2006:153, Arendt 2006:292). That is why in resonating the evil nature of their actions there appears a banality of evil that didn't extend to them. In all of the mentioned disqualifications, Eichmann, Stangl, Höss, and others, have shown consideration only towards minuscule, precise, effective and thought-out completion of their loosely understood duty, and the bureaucracy and administration of the apparatus of extermination. Moreover, even those the likes of Schtangel (the leader of the most infamous Polish death camps) that were in almost immediate contact with their victims couldn't identify with the captives, but only felt contempt on the basis of all the traits that they themselves possessed (Svendsen 2006:157). We have already pointed out several moments in the discussion about the banality of evil by which the radical nature of this type of evil, that is, the radical nature of the spontaneity of human compensation and their subordinance to ideologies. Naturally, if we identify the banality of evil in the same sense that Arendt and Kant's radicalism identified, we will point to the debate about the very nature of human society because the specified identification directly points at the would-be innate predisposition to dehumanise the other. This is in itself a whole another debate, and one that reaches beyond the confines of this work.

As was previously noted, the general nature of the Eichmann trial, being a "cogwheel of the monstrous mechanism of Nazism", as Arendt explains in the Epilogue of the report On the Banality of Evil, is a suitable and sufficient reason to conclude that from Eichmann's substantial connection to the system, it is not him that is on trial, but Nazism in general. A type of institutional crime gains an unprecedented amount of power, which it uses to judge the nature of a system based not on the parts by which it is formed, but rather on its initial 
totality, making the consequences more far-reaching and making them seem almost irrational, which, in an ironic turn of events, is actually proportionate to the actual crime. In so doing, the court keeps its own humanism and apparatus, which appears to be incapable of containing evil, and sets it beyond evil itself, when it is actually but the first large symptom of the permissiveness of neoliberal politics of our contemporary moment in which we are the witnesses of a certain proliferation of ultra-right movements across Europe and the world.

The law in the sense of judging evil appears as a general call of (moral) conscience, and not as a constructed political code of rights and prohibitions; punishment and reward, or rather the "live and let live" position. From there, we cannot talk about the collective guilt or innocence (except in the framework of the previous statement). The category of political responsibility, which cannot be judged as a criminal action (Arendt 2006:301) has been thrown out of the juridical system. Evil hasn't become latent and its evolution doesn't follow the modern crisis of identity (Sućeska 2008), rather, it is the ongoing process of incubation that can be inferred from its intelligence (Baudrillard 2005:159-191), and its omnipotent position stems from the fact that the very term has been transformed into a universal political marker, and has been assigned a dynamic ability to move between the juridical and the moral, where it "plays" on two fields, which allows it to endure. Displaced, mediatised and incubated evil is no longer an idea, but a "bogeyman", the burden of certain politics and decisions in the shaping of the contemporary moment in which the end of the Second World War appears as an epochal moment. Up until Eichmann, evil was "dependant". Evil being on trial depended on the criminal who identified with evil and as such accepted or rejected it. Now it shows its political and discursive nature; in place of force it becomes the true signifier of power. Juridical power cannot stand against the magnitude of the presumed and actualized crime in the twentieth century, and most certainly not against the former pattern of the valorisation and the choice of the appropriate punishment, and crime. The trial process in principle places punishments on individuals (with the exception of international disputes and those that appear as a consequence of war), which are of existential character. On the other hand, in the given case, the same individual is on trial for a universal crime - Nazism. Here, finally, the important political substantiality of the problems of thought and evil are revealed. Individual trial cases prosecuting generality in a given historical context incubate the ideological "balloon" of the evil nature of political extremism. The question is whether all Nazis should be put to trial or how to put Nazism on trial; however, however, they are wrapped into a worldwide taboo about the attempt to reconcile such actions with neoliberal politics of our time.

Thinking of the victims of Auschwitz should once more remind us of the suffering that arises from this cruel manifestation, and whose nature cannot be found in the depths of philosophical reflexion, but in the motivation of progress and the "disenchantment" of evil which is categorically involved in the discourse of modern day life. In which way we can and should contemplate on it is a question because of which obscure theories must be brought into the field of practical action, and offer the necessary differentiation of the border between evil and punishment, the political and the moral. Their tying together can often lead to real, and practical, rather than feasible problems history must deal with. Similarly, with incubation, one should begin to think outside the patters of the interpretation of evil as a pageant of crimes that already happened in order to reveal the flow of the symbolic transfer of 
evil nature, and to recognize the particular forces that make evil an important segment of modern day society in which we live and for which we live. It is about the philosophical task to find terms, which - although it is already a particular praxis in itself - demands something more than spiritual activities of individual philosophical efforts.

\section{Bibliography}

Amherdt, François-Xavier (2010): "Paul Ricœur i skandal zla: izazov za filozofiju i teologiju" ["Paul Ricœur and the Scandal of Evil: A Challenge for Philosophy and Theology"], in: Obnovljen život 65 (4/2010), pp. 485-496.

Arendt, Hannah (2006): Eichmann in Jerusalem. A Report on the Banality of Evil. London: Penguin Classics.

Arendt, Hannahh (1951.) The Origins of Totalitarianism. New York: Harcourt Brace.

Badiou, Alain (2001): Ethics. An Essay on the Understanding of Evil. London: Verso.

Baudrillard, Jean (2005): The Intelligence of Evil. Or the Lucidity Pact. New York: Berg.

Birmingham, Peg (2003): "Holes of Oblivion. The Banality of Radical Evil", in: Hypatia 18 (1/2003). pp. 80-103. doi: https://doi.org/10.1353/hyp.2003.0003.

Debord, Guy (1999): Društvo spektakla [The Society of the Spectacle], translated by Goran Vujasinović. Zagreb: Arkzin.

Gerson, Lloyd P. (2006): The Cambridge Companion to Plotinus. Cambridge: Cambridge University Press.

Hegel, Georg Wilhelm Friedrich (2001): The Philosophy of History, Kitchener: Batoche Books.

Hösle, Vittorio (1996): Filozofija ekološke krize [Philosophy of the Ecological Crisis: Moscow Lectures], translated by Darija Domić. Zagreb: Matica hrvatska.

Jonas, Hans (1990): Princip odgovornost. Pokušaj jedne etike za tehnološku civilizaciju [The Imperative of Responsibility: In Search of an Ethics for the Technological Age], translated by Slobodan Novakov. Sarajevo: Veselin Masleša.

Kant, Immanuel (1998): Religion within the Boundaries of Mere Reason. And Other Writings. Cambridge: Cambridge University Presss.

Löwith, Karl (1949): Meaning in History. Chicago: University of Chicago Press.

Marquard, Odo (1989): Farewell to Matters of Principle. New York: Oxford University Press.

Paić, Žarko (2015): Tré́a zemlja: tehnosfera i umjetnost [The Third Land: Technosphere and Art]. Zagreb: Litteris.

Paić, Žarko (2013): Sloboda bez moći. Politika u mreži entropije [Freedom Without Power: Politics in the Entropy Network]. Zagreb: Udruga Bijeli val.

Pearson, Keith Ansell (ur.) (2006): A Companion to Nietzsche. Oxford: Blackwell publishing. Plotin (1984): Eneade [Enneads] 1-2, translated by Slobodan Blagojević. Beograd: Književne novine.

Sućeska, Alen (2008): "Osjećaj političke suvišnosti i evolucija zla" ["The Feeling of Political Superfluosity and the Evolution of Evil"], in: Diskrepancija 8 (1/2008), pp. 49-59.

Sontag, Susan (2005): Prizori tudeg stradanja [Regarding the Pain of the Others], translated by Božica Jakovlev. Zagreb: Algoritam.

Svendsen, Larš Fredrik [Svendsen, Lars Fredrik] (2006): Filozofija zla [Philosophy of Evil], translated by Nataša Ristivojević Rajković. Beograd: Geopoetika.

Vitaljić, Sandra (2013): Rat slikama [Image Wars]. Zagreb: Algoritam.

Williams, Raymond (2006): "Analiza kulture" ["The Analysis of Culture"], in: Duda, Dean (ed.), Politika teorije. Zbornik rasprava iz kulturalnih studija [The Politics of Theory. Collected Papers on Discussions in Cultural Studies], pp. 35-63. Zagreb: Disput. 


\title{
Dario Vuger \\ Inkubacija zla: \\ zlo kao problem čovjekova mišljenja i prakse
}

\begin{abstract}
Sažetak
Na tragu promišljanja zločina nacizma Hannah Arendt u radu se tematizira odnos fenomena zla u suvremenosti u kojoj se identificira niz problema koji mogu poslužiti kao prilog budućem istraživanju zla kao problema prakse. Arendt piše o zlu suočena sa suđenjem jednome od najvećih nacističkih zločinaca, Adolfu Eichmannu, koje je do danas bitno utjecalo na teoretiziranje zla. Po prvi se puta dosljedno uvodi u raspravu zlo kao problem savjesti, odnosno unutarnjeg dijaloga kao kontemplativne naravi našeg djelovanja koja nas čini osobama. Zlo je, u obliku s kojim se susreće Arendt, opisano kao banalno, kao zlo koje čini čovjek bez priziva savjesti, kao produkt ne-mišljenja. Pritom je riječ o pukom izvršenju operacija gdje je zlo globalno, ali sam čin individualan. Takvo zlo može biti opisano i kao radikalno zlo koje se događa potpunom asimilacijom pojedinaca u sistem proizvođenja, birokratizacije i industrijalizacije gdje se Ja predaje volji procesa koji ostaje nepoznat. Danas se zlo ne događa kao asimilacija, nego se izmješta iz svakodnevice. U tomu se horizontu zlo inkubira u mjesta svjetskih sukoba i svjedoči o sebi putem medijskih reprezentacija koje sugestivnom politikom stvaraju topografije zla, a svojim uspostavljanjem lišavaju nas obveze da svoje vlastite akcije promatramo unutar okosnice zla i dobra jer je svakodnevica lišena operatora s kojima bismo to mogli činiti sa sigurnošću da nećemo upasti u diskurs konzervativizma ili drugih selektivnih tradicija koje ne odgovaraju konkretnom društveno-političkom bitku tehnosfere u kojoj živimo. Naime, zlo ima svoj čvrst temelj u metafizici i svakako je nadležno raspravi o pravednosti (društvenoj mistifikaciji dobra) ili kazni (opravdanom zlu), ali to ne znači da zlo počinje i završava u kategoričnoj nepomičnosti izvan svijeta pokretnina. Zlo je fluktuirajuća točka nemira unutar slobode koju smo stvorili da bismo ga izbjegli. U trenutku kada se razračunavamo sa svojom neposrednom poviješću potrebno je osuvremeniti mišljenje o zlu kao fenomenu koji je nezaobilazan predmet svake prakse koja smjera nadvladavanju konkretnih nepravednosti naše svjetsko-povijesne duhovne situacije.
\end{abstract}

Ključne riječi

zlo, Hannah Arendt, mišljenje, praksa, inkubacija, izmještanje

\section{Dario Vuger \\ Inkubation des Bösen: das Böse als Problem des menschlichen Denkens und der Praxis}

\section{Zusammenfassung}

Auf der Spur von Hannah Arendts Reflexionen über die Verbrechen des Nazismus wird in der Arbeit das Verhältnis zum Phänomen des Bösen in der Moderne thematisiert, in welcher eine Reihe von Problemen identifiziert wird, die als Beitrag zur zukünftigen Untersuchung des Bösen als Problem der Praxis dienen können. Arendt schreibt über das Böse, konfrontiert mit dem Gerichtsprozess gegen einen der größten Nazi-Verbrecher, Adolf Eichmann, also dem Prozess, der die Theoretisierung des Bösen bis heutzutage belangreich beeinflusst hat. Zum ersten Mal wird das Böse konsequent in die Erörterung eingeführt, und zwar als ein Problem des Gewissens bzw. des inneren Dialogs als kontemplative Natur unseres Handelns, die uns zu Personen macht. Das Böse wurde in der Form, wie ihr Arendt begegnet, als banal geschildert, als Böses, welches der Mensch ohne den Gewissensappell antut, als ein Produkt des Nicht-Denkens. Dabei ist die Rede von einer bloßen Ausführung von Operationen, wobei das Böse global und der Akt selbst jedoch individuell ist. Ein derartiges Böses lässt sich ebenso als ein radikales Böses beschreiben, das durch die vollständige Assimilation von Individuen in das System der Produktion, der Bürokratisierung und der Industrialisierung geschieht, wo sich das Ich dem Willen eines unbekannt gebliebenen Prozesses ergibt. Heutzutage vollzieht sich das Böse nicht als Assimilation, sondern es wird aus dem Alltag ausgelagert. In diesem Horizont inkubiert sich das Böse in den Schauplätzen der Weltkonflikte und zeugt von sich selbst anhand der Medienrepräsentationen, die mittels suggestiver Politik Topografien des Bösen schaffen und uns durch ihre Etablierung von der Verpflichtung entbinden, eigene Handlungen im Rahmen der Grundzüge des Bösen und des Guten zu beobachten. Denn der Alltag ist der Operatoren beraubt, mit denen wir dies tun könnten, und zwar mit der Sicherheit, nicht auf den Diskurs des Konservativismus oder anderer 
selektiver Traditionen einzugehen, die nicht dem konkreten gesellschaftspolitischen Sein der Technosphäre, in der wir leben, entsprechen. Das Böse, nämlich, hat ein solides Fundament in der Metaphysik und ist sicherlich maßgeblich für die Diskussion über die Gerechtigkeit (gesellschaftliche Mystifikation des Guten) oder die Strafe (gerechtfertigtes Böses), allerdings bedeutet dies nicht, dass das Böse in einer kategorischen Bewegungslosigkeit außerhalb der Welt des Bewegten beginnt und endet. Das Böse ist der fluktuierende Punkt der Unruhe innerhalb der Freiheit, die wir geschaffen haben, um es zu vermeiden. In dem Augenblick, in welchem wir uns mit unserer unmittelbaren Geschichte auseinandersetzen, ist es notwendig, die Idee des Bösen als eines Phänomens zu erneuern, das ein unentbehrlicher Gegenstand jeglicher Praxis ist, welche die Überwindung konkreter Ungerechtigkeiten unserer weltgeschichtlichen geistigen Situation anstrebt.

\title{
Schlüsselwörter
}

Böses, Hannah Arendt, Denken, Praxis, Inkubation, Auslagerung

\section{Dario Vuger \\ L'incubation du mal : \\ le mal en tant que problème de la pensée et de la pratique de l'Homme}

\begin{abstract}
Résumé
Sur la trace des réflexions sur les crimes du nazisme de Hannah Arendt, ce travail thématise la relation des phénomènes du mal dans le monde contemporain au sein duquel une suite de problèmes qui ont été identifiés peuvent servir de contribution aux futures recherches. Arendt écrit sur le mal en étant confrontée à l'un des plus grands criminels nazis, Adolf Eichmann, qui a jusqu'à présent largement influencé la théorisation du mal. Pour la première fois, le mal est introduit dans le débat de manière cohérente comme problème de conscience, à savoir comme dialogue interne qui se comprend comme nature contemplative de notre action et qui fait de nous des personnes. Le mal est, sous la forme avec laquelle Arendt est confrontée, décrit comme banale, comme mal qui définit l'Homme sans faire appel à la conscience, comme un produit de la non-pensée. Ensuite, il est question de la simple exécution de l'opération où le mal est global, et le fait même individuel. Un tel mal peut être décrit comme un mal radical qui se produit par le biais d'une complète assimilation de l'individu au système de production, de bureaucratisation, d'industrialisation où le Je s'adonne à la volonté du processus qui reste méconnu. C'est dans cette horizon que le mal est incubé dans des lieux de conflits mondiaux et témoigne de lui à travers la représentation des médias qui, par une politique suggestive, créent des topographies du mal, et qui, par leur constitution, nous privent de l'obligation d'observer nos propres actions à l'intérieur de l'axe du mal et du bien car le quotidien est privé d'opérateurs avec lesquels nous pourrions effectuer cela de manière sûre, ce qui pourtant nous éviterait de tomber dans le discours du conservatisme ou dans d'autres traditions électives qui ne répondent pas à la lutte politico-sociale de technosphère dans laquelle nous vivons. En effet, le mal a son fondement ferme dans la métaphysique et il est absolument soumis au débats de la justice (à la mystification sociale du bien) et à la peine (au mal justifié), mais cela ne signifie pas que le mal commence et finit dans une immobilité catégorique au-delà du monde en mouvement. Le mal est une situation fluctuante de tourments au sein d'une liberté que nous avons créé afin d'y échapper. À l'instant où l'on règle ses comptes avec l'histoire immédiate, il est nécessaire de rendre contemporain la pensée sur le mal en tant que phénomène, objet incontournable de chaque pratique qui tend à dépasser les injustices concrètes de notre situation spirituelle historico-mondiale.
\end{abstract}

\section{Mots-clés}

mal, Hannah Arendt, pensée, pratique, incubation, déplacement 